\title{
Improving the Creative Thinking Skills of the Next Generation of Mathematics Teachers Using Dynamic Mathematics Software
}

\author{
https://doi.org/10.3991/ijet.v16i13.21535 \\ Tommy Tanu Wijaya, Ying Zhou $(\bowtie)$ \\ Guangxi Normal University, Guilin, China \\ zhouying66@mailbox.gxnu.edu.cn \\ Andrew Ware \\ University of South Wales, Wales, UK \\ Neni Hermita \\ Universitas Riau, Pekanbaru, Indonesia
}

\begin{abstract}
The case study reported in this paper investigated the effect of project-based learning on students training to be mathematics teachers, pursuing their final projects. The final projects had the aim of designing attractive and interactive mathematics learning material. The case study used a qualitative method to assess the impact on the trainee teachers in terms of their creative design thinking. The research made use of the Hawgent dynamic mathematics software package. The study participants were all students at Guangxi Normal University, China. The students were divided into three groups, each with four or five members. The results presented show that selecting material and combining it with art using dynamic mathematics software can improve prospective teachers' communication skills, problem-solving ability, creative thinking, and self-confidence. Moreover, the future mathematics teachers needed motivation and support during their project's lifecycle, which, in turn, had a positive effect on self-confidence.
\end{abstract}

Keywords-Mathematics teaching, creative thinking, dynamic mathematics software, project-based learning

\section{Introduction}

Many learners at all stages of study perceive mathematic lessons as challenging to understand and monotonous [1-4]. The reasons for such perceptions are varied but include the fact that mathematical material is often abstract [5-7]. Abstraction is frequently tricky for children, particularly younger ones [8-9].

De Porter in Chotimah [10] showed that humans can absorb 70\% of knowledge when its acquisition involves them in active participation, $50 \%$ when it involves visual observation and hearing, 30\% when it involves only visual observation, $20 \%$ when 
it involves only hearing, and just $10 \%$ when merely reading. From De Porter's research, we can surmise that mathematics lessons in class would be more effective if the pedagogical approach required learners' active autonomous participation.

Many school children are proficient with technology [11-14] that can facilitate their learning. Often, however, a lack of technology-related pedagogy skills amongst teachers can be an issue [15]. Nonetheless, recently, there has been a drive to change the perception of mathematics education through technology in teaching and learning activities [16].

Research shows that the use of technology in teaching and learning activities can improve mathematical capability [17-18], increase reasoning skills [19], engender interest in learning [20], and enhance engagement within the classroom. Against this backdrop, there has been an increased impetus to develop learning material using various dynamic mathematics software packages, including Hawgent, to improve mathematics teaching effectiveness [21-23].

Due to its importance, creative thinking ability is one of the metrics used by the Program for International Student Assessment (PISA) [24-26]. Given that it is a PISA assessment metric, most countries focus on improving learners' creative thinking ability [27-29]. Furthermore, when learners have creative thinking ability, they are better equipped to solve problems and develop innovative solutions in various scenarios [30].

Prospective mathematics teachers need creative thinking to solve problems in new and innovative ways. Enhancing their creative thinking abilities better prepares mathematics teachers for the classroom. It will help them be innovative when developing learning activities for class and be adaptive to children's needs to understand abstract mathematical topics. However, to enhance prospective mathematics teachers' creative thinking abilities, educators must develop their skill and the wherewithal to pass them on.

Many countries in Asia still use 'chalk-and-talk' methodologies supplemented with requiring learners to practice and improve their mathematical abilities [31-33]. Based on many studies, the use of technology in education has proved to have many advantages over more traditional approaches [34-38]. Moreover, there was reason to expect that combining project-based learning (PBL) and technology can produce even better results. Based on this premise, the research investigated how project-based learning utilizing dynamic mathematics software could improve future mathematics teachers' creative thinking abilities.

The project-based learning (PBL) approach has been around since 1997 and is considered helpful in improving learners' performance. The PBL approach is a combination of design thinking, problem-solving, and decision-making. PBL focuses on learner activity, with teachers acting as facilitators and transmitters of knowledge. Learners benefit by improving their problem-solving, design, and decision-making skills. In contrast to many traditional approaches, where learners are passive participants, PBL makes students active, requires them to think, and often collaborate. Project-based learning has been shown to have a positive effect on creative thinking, communication and teamwork [39-40], and self-confidence. For example, Khairunnisa [41] showed that using project-based learning, with children, positively affected collabora- 
tion and teamwork, increased their self-confidence, creative thinking, willingness to take risks and express new ideas.

Mohamadi Z [42] compared PBL with ePBL in English lessons. He found that PBL and ePBL had the same positive effect on students' English skills. Besides that, Caroline [43] showed PBL to be a key element in enhancing the impact of science, Technology, Engineering, and Mathematics (STEM) education. Other studies on PBL, in the field of engineering [44] and learners in high schools and university [45], have highlighted its positive impact on learning outcomes [46]. However, there is far less research on the effect of PBL assisted by dynamic mathematics software and its relationship with learners' creative thinking and problem-solving abilities. Thus, this paper fills a gap by exploring the impact of project-based learning, combined with the use of dynamic mathematics software.

Hawgent dynamic mathematics software, designed for easy use in mathematics education [47], can be used by teachers to explain the mathematics material and by students outside of class. The Hawgent software can be used to visualize various mathematical concepts such as geometric shapes, algebra, trigonometry, statistics, probability, algorithms and many other materials [48].

Xiangjie Z. et al. [49] used Hawgent to help teach the concepts of Line and Angle. They found that students' understanding and ability to answer questions was much improved. Lin Suan et al. [21] developed learning media with the theme of ethnomathematics on arithmetic material and the learning media received positive responses from teachers and students. On the topic of plane geometry, Chotimah S. et al. [19] tried to improve their reasoning ability with the help of Hawgent. Chotimah's research results show that Hawgent has helped junior high school students improve their student reasoning abilities.

While many studies have used Hawgent to enhance mathematics teaching, they have focused on developing instructional media and improving students' ability. Moreover, while many researchers have investigated its use with children, none have used it to improve trainee mathematics teachers' creative thinking abilities.

Given the lack of research in the area, the work articulated in this paper studied the use of Hawgent to improve the creative thinking ability of trainee mathematics teachers through its use in project-based learning.

Study participants were required to choose a topic of interest and then, using the Hawgent software, design and develop appropriate and effective teaching material, including an element of artwork. Participants were then required to evaluate the learning material in terms of its suitability for use in a school environment and suggest ways to improve it.

This paper focuses on prospective mathematics teachers' creativity when developing the learning material and their lecturers' evaluation. Other aspects of the research will be reported elsewhere. 


\section{$2 \quad$ Method}

The study used quantitative methods to determine the creative thinking steps taken by the participants when developing an animation linked to their chosen topic. The study addressed the questions: Do participants explain how their idea originated? Why did they choose the material used? How did they create their project? What skills were needed to complete the project?

The curriculum delivered over five months (one semester), from March 2020 until June 2020, involved twice-weekly sessions. The overall curriculum material and lesson plan for each session were as follows:

- March 2020: introduction, brainstorm, mathematics and art, creativity in mathematics lesson (4 weeks)

- April 2020: introduction to Hawgent dynamic mathematics software (4 weeks)

- May 2020: In the first week, participants determined the material they would develop. In the second and third week, they designed their projects using Hawgent dynamic mathematics software. In the fourth week, participants held discussions with their lecturers about their project and, in the final week, they revised the projects in the light of those discussions.

- June 2020: revision and final presentation

The study involved three groups, each of either four or five participants, from Guangxi Normal University. Each group was interviewed for between 20 and 30 minutes to understand their creative thinking process. The interviews, conducted in a semi-structured manner, give flexibility for additional questions to be asked depending on previous responses.

During the interviews, participants from other groups were allowed to ask questions and make suggestions, with the idea that this peer-to-peer input would facilitate better overall ideas. Interviews were conducive to participants sharing their thoughts freely. Moreover, several professors, media and material experts provide suggestions and an informal evaluation of each project. The Informal evaluation by media expert focused on appearance, ease of use, animation, enrichment. In contrast, the informal evaluation by the material expert focused on how worthwhile the project might be in helping children understand the mathematics concept.

\section{Results and Discussion}

Each group used a problem-based learning approach to carry out a creative thinking project using dynamic mathematics software. The groups saw the task as challenging and raised issues, including "how can mathematical material be used to create an interesting project related to everyday life?". Attitudes correlated with previous research that suggests that students see mathematics as a complex subject.

This study had creative activities in mind during its design and an evaluation process that encouraged collaboration. Each group followed the exact step-by-step process from analysis, design, development, implementation and evaluation. 
Groups were required to analyze their chosen problem, design, develop, and implement using the Hawgent software, helpful learning material that should use relevant and exciting art. After implementation, they had to evaluate were required to evaluate whether their work would be helpful for teachers and school children. The study found that each step in the process increased communication skills, problemsolving abilities, creative thinking dexterity, and self-confidence.

Mirsha and Koehler [50] show that designing teaching media cannot be taught conventionally. The design depends on experience, creative thinking processes, needs and continuous evaluation. Moreover, Aflatoony [51] reported that design thinking could improve creative thinking, communication, and teamwork.

In the ninth week of the study, when the participants had mastered how to use Hawgent dynamic mathematics software, they were informed that, in groups, they had to produce learning media based on their observations at school. The participants immediately began to form mental blocks, with some saying that the task was challenging.

The participants were not confident in integrating technology, preferring to use traditional teaching methods in the classroom. This view is in line with previous research that shows that the education world is often more comfortable in an environment that does not use technology.

The view participants changed during the study, which saw them grow in confidence as they engaged proactively with the software. Moreover, their awareness of how the technology could benefit their teaching also increased. This finding is in line with previous research showing that project-based learning can increase student interest in learning. To better understanding the study, the work of each of the three groups is briefly outlined.

Group 1 chose to base their project around material for an algebra lesson. The groups planning for their project, which they named "cute cube algebra", can be seen in Figure 1. The figure maps the step-by-step creative thinking process of the group.

At the analysis stage, the group perceive algebra as an abstract subject. Algebra contains tedious and difficult to understand formulas. Therefore, Group 1 took the algebraic formula $(a+b) 3=a 3+3 a 2 b+3 a b 2+b 3$ and created an interesting and colorful media. The group hoped that this learning media could change high school students' mindset on algebra at the interview stage. They hope that it can increase children's interest in studying algebra. The group combine algebra formulas and art to produce interesting learning media using Hawgent dynamic mathematics software at the design stage.

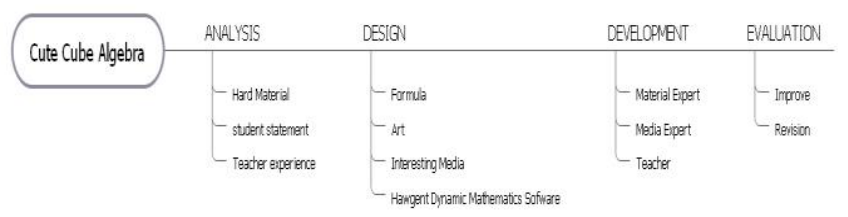

Fig. 1. Group 1's creative thinking process in designing the learning for "cute cube algebra". 
Figure 2 shows a full-colour 3D view of the group's final project. Blocks represent the formula, and the learning media has a slider to open and close the cube. Table 1 shows the evaluation results. Following feedback, the group added sound to their implementation to make it more appealing. Moreover, the material expert suggested that the work could be into video-based learning.

Table 1. Group 1: Assessment result by media and material experts.

\begin{tabular}{|l|l|c|c|}
\hline & \multicolumn{1}{|c|}{ Indicator } & Score & Percentage \\
\hline \multirow{4}{*}{ Media expert } & Appearance & 16 & $80 \%$ \\
\cline { 2 - 4 } & Animation & 17 & $85 \%$ \\
\cline { 2 - 4 } & Easy to use & 15 & $75 \%$ \\
\cline { 2 - 4 } & Enrichment & 18 & $90 \%$ \\
\hline \multirow{5}{*}{ Material Expert } & Easy to Understand & 18 & $90 \%$ \\
\cline { 2 - 4 } & $\begin{array}{l}\text { Help students to understand the basic concepts } \\
\text { of algebra formula }\end{array}$ & 18 & $90 \%$ \\
\cline { 2 - 4 } & $\begin{array}{l}\text { Can improve Junior High School students' } \\
\text { interest in learning }\end{array}$ & 19 & $95 \%$ \\
\hline
\end{tabular}

Note: Maximal score is 20 .

Brezovszky et al.'s study showed that algebra is a complex subject to teach because of its many formulas. However, the learning material produced by Group 1 can help students understand algebraic concepts without the need to memorize formulas.
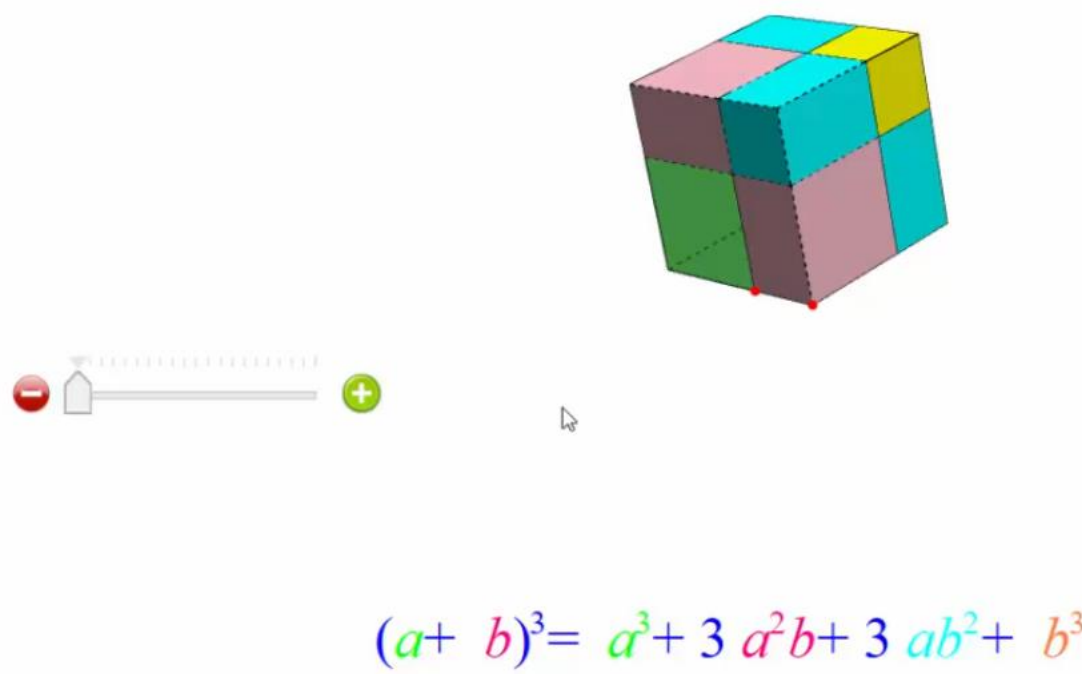

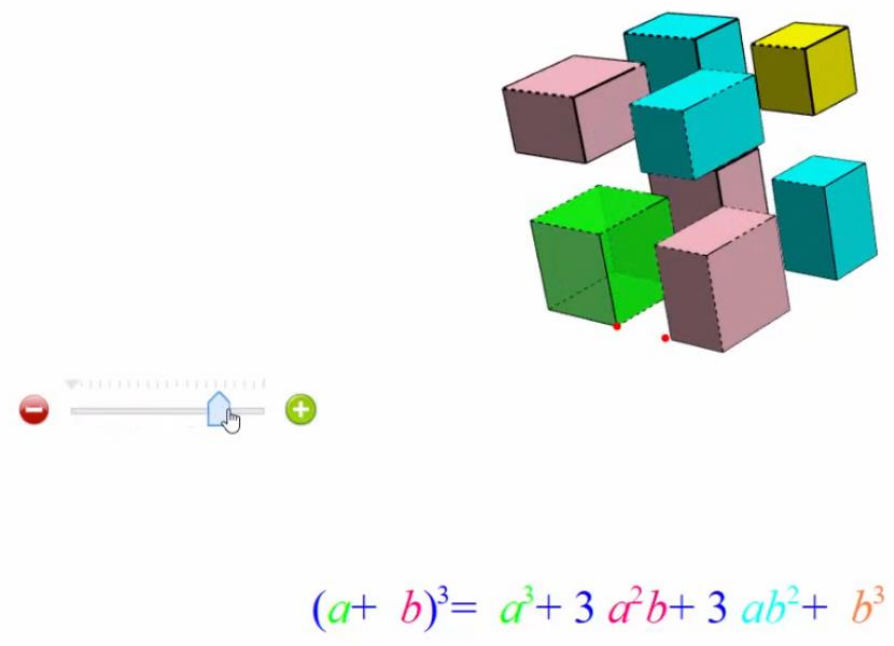

Fig. 2. "Cute cube algebra" created by Group 1.

Group 2 visited an elementary school in order to find suitable materials for use in their project. After observing various classes, the group opted to develop material related to two-dimensional figure material that they had seen taught to Grade 5 children. The group's initial idea was to use the basic pentagon structure to teach about folding symmetry. However, after discussion, the group settled on the less ambitious idea of making starfish using pentagons.

Initially, the implementation involved starfish that did not move. However, following feedback from the media expert, a modification was made that enabled the tentacle to move. Further feedback from the teacher at the school led to the starfish having a more attractive colour. The group's evaluation results are shown in Table 2, while the left and right images of Figure 3 show the original and revised implementation, respectively. The group gave their project the title "Pentagon Starfish", Figure 4 shows their creative thinking process.

Table 2. Group 2: Assessment result by media and material experts.

\begin{tabular}{|l|l|c|c|}
\hline \multicolumn{1}{|c|}{ Indicator } & Score & Percentage \\
\hline \multirow{4}{*}{ Media expert } & appearance & 15 & $75 \%$ \\
\cline { 2 - 4 } & animation & 19 & $95 \%$ \\
\cline { 2 - 4 } & easy to use & 16 & $80 \%$ \\
\cline { 2 - 4 } & Enrichment & 15 & $75 \%$ \\
\hline \multirow{3}{*}{ Material Expert } & Easy to Understand & 17 & $85 \%$ \\
\cline { 2 - 4 } & help students to understand the concepts of congruent & 17 & $85 \%$ \\
\cline { 2 - 4 } & Can improve elementary students' interest in learning & 19 & $95 \%$ \\
\hline
\end{tabular}

Note: The maximal score is 20 . 


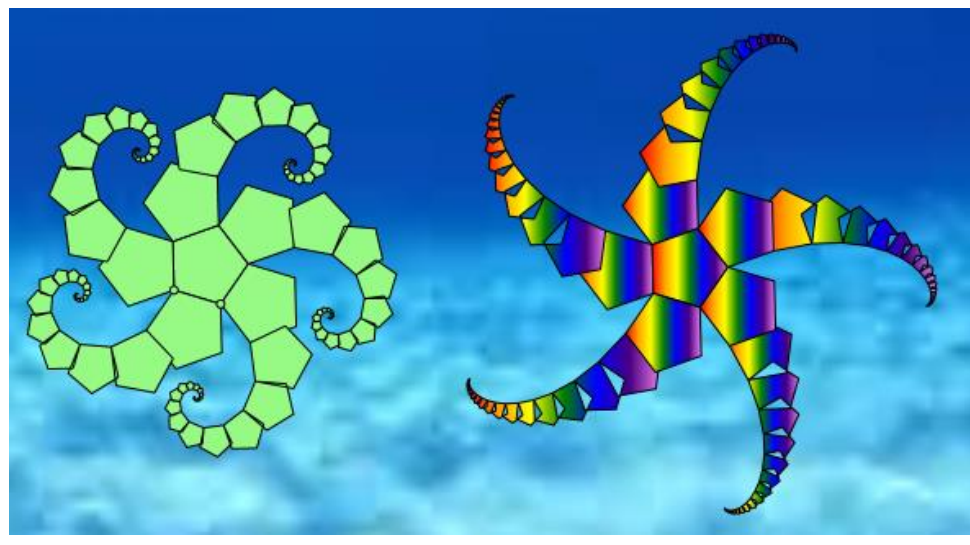

Fig. 3. "Pentagon Starfish" created by Group 2.

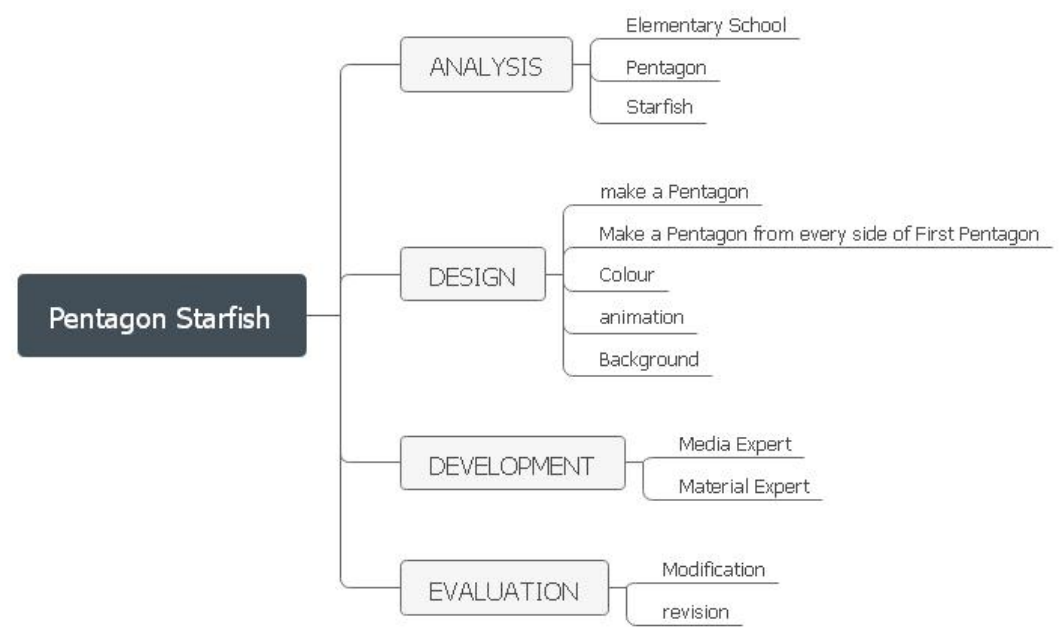

Fig. 4. Group 2's creative thinking process in designing the learning media for the "Pentagon Starfish."

Group 3's project looked at trigonometry, a subject whose basics must be mastered by school children before they progress later in life to more in-depth calculus courses. If a learner does not like trigonometry lessons, they will find it challenging to grasp the material's concept. Group 3 thus created learning media with a touch of art to make trigonometry lessons more exciting and fun. They named their project "Trigonometric fish" (see Figure 5). 


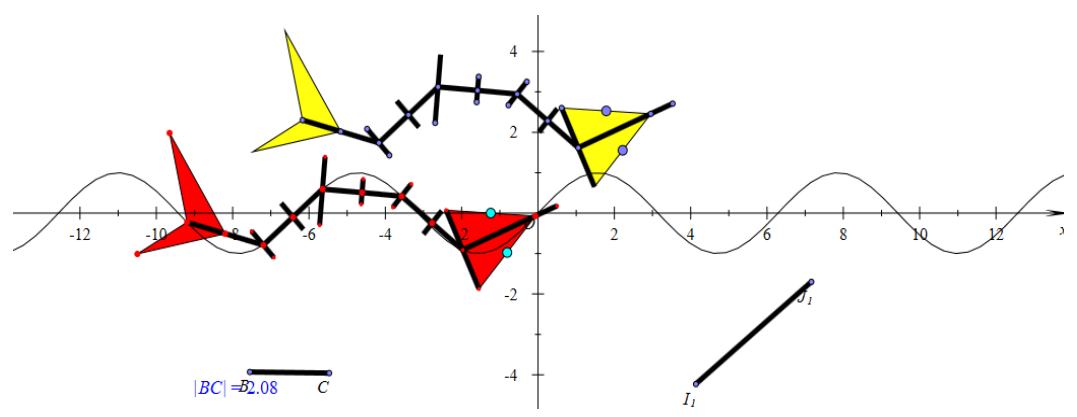

Fig. 5. "Fish with Graph of Sine" created by Group 3.

Figure 6 shows the group's creative thinking. The group's first step was to make a sine graph to represent a fish track. However, they found that the cos graph can also be used as a fish track. Based on the sin and cosine graph, the group then make each part of the fish's head, body, and tail. The root of the mathematical context was not lost; the group made a fish head with an isosceles triangle shape and a fishtail using triangles. The group also added animation to move the fish according to the sine or cosine trajectory. When the group used the material in a classroom setting, it received a positive response from the children with a clear indication that they enjoyed the material and, through its use, understood the concepts taught. Table 3 shows the project's evaluation.

Table 3. Group 3: Assessment result by media and material experts.

\begin{tabular}{|l|l|c|c|}
\hline \multicolumn{1}{|c|}{ Indicator } & Score & Percentage \\
\hline \multirow{4}{*}{ Media expert } & \multicolumn{1}{|c|}{ Appearance } & 16 & $80 \%$ \\
\cline { 2 - 4 } & Animation & 17 & $85 \%$ \\
\cline { 2 - 4 } & Easy to use & 18 & $90 \%$ \\
\cline { 2 - 4 } & Enrichment & 17 & $85 \%$ \\
\hline \multirow{5}{*}{ Material Expert } & Easy to Understand & 16 & $80 \%$ \\
\cline { 2 - 4 } & $\begin{array}{l}\text { Help students to understand the graphs concepts of } \\
\text { Sine and Cosine }\end{array}$ & 16 & $80 \%$ \\
\cline { 2 - 4 } & $\begin{array}{l}\text { Can improve Senior High School students' interest } \\
\text { in learning }\end{array}$ & 17 & $85 \%$ \\
\hline
\end{tabular}

Note: The maximal score is 20 .

At the evaluation stage, the teacher at the school suggested making the trigonometric fish look more natural and alive by adding a sea background. However, the group concluded that such would obfuscate the trigonometric impression and that the children may not understand that it is a graph of the trigonometric function. 


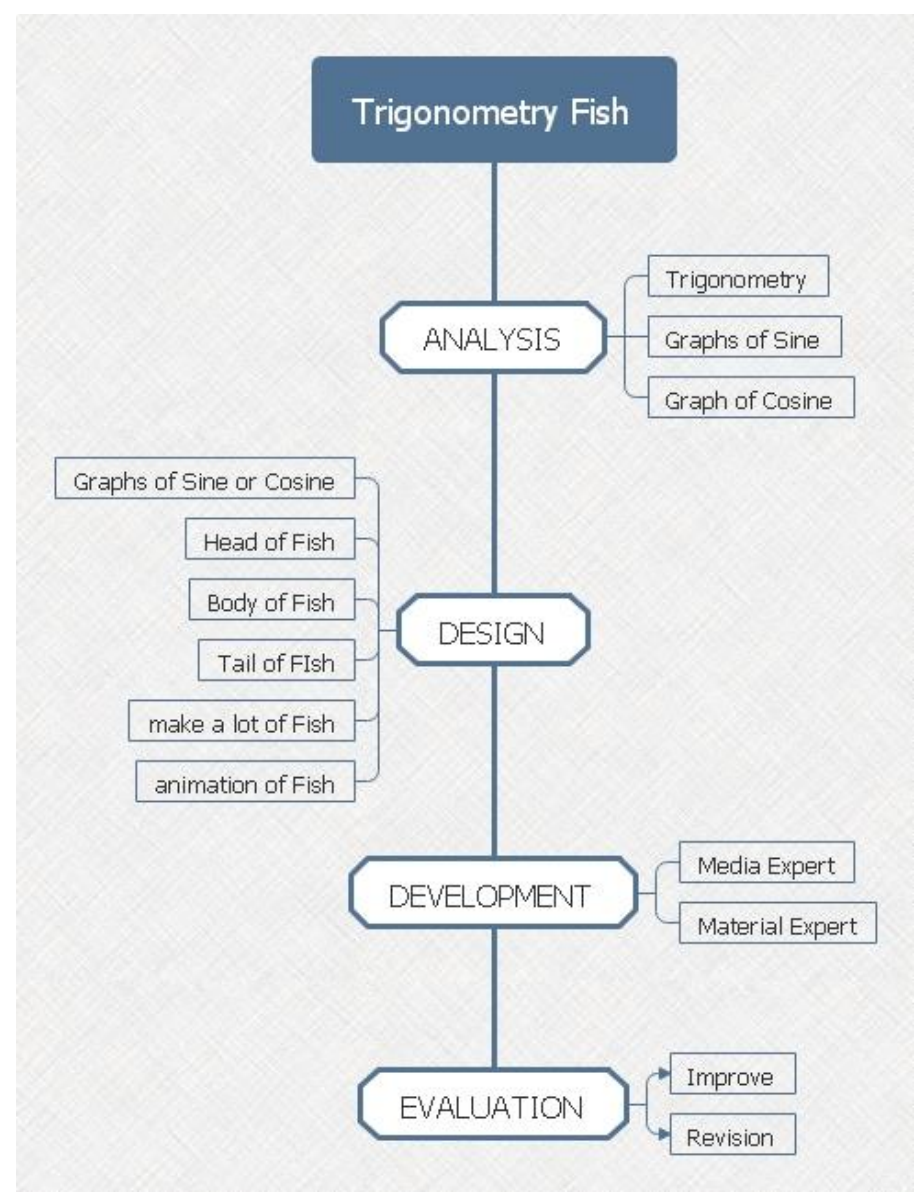

Fig. 6. Group 3's creative thinking process in designing the learning media for the "Trigonometry Fish".

From the participants initial perspective, choosing a mathematical topic and combining it with art using dynamic mathematics software is not easy. Nonetheless, each group worked well on their project, with the PBL approach providing opportunities for them to develop their creative thinking skills. The effect of PBL on creative thinking and led to innovative work suitable for use in schools.

The study showed that with PBL, groups demonstrated teamwork throughout their project. Group members engaged in dialogue to ensure they produced the best work. From this discussion, participants problem-solving abilities also increased. At the implementation stage, the presentations made by the groups increased self-confidence and ability to defend the decisions they had made. 


\section{Conclusion}

Many studies have been conducted into the development and use of technologybased learning media to improve students' mathematical abilities. However, there is little research on prospective mathematics teacher's creativity when developing a project by combining mathematics technology.

The study reported in this paper investigated the benefits of implementing projectbased learning approach with prospective mathematics teachers, studying at university, doing their final projects. The study found that the students improved their communication and problem-solving skills, creative thinking ability, and self-confidence.

Furthermore, the study found that motivation plays a crucial part that encourages future mathematics teachers to be more confident in solving problems. This study also illustrates the importance of teaching design thinking and problem-solving strategies at university.

The research study was limited to the use of Hawgent software. Future study can extend the work to consider other mathematics software. Moreover, the research did not use quantitative methods to get specific results about the differences in creative thinking prospective and abilities of participants.

\section{Acknowledgement}

This research was funded by Guangxi Higher Education Undergraduate Teaching Reform Project "Research and practice of effective mathematics teaching guided by systematic thinking ability" (2019JGZ110) and Guangxi Graduate Education Innovation Plan Project "Research on training mode of improving high-level thinking ability" (XJGY2020010).

\section{References}

[1] Reis, Z. A. (2010). Computer supported mathematics with Geogebra. Procedia - Social and Behavioural Sciences, 9, 1449-1455. https://doi.org/10.1016/j.sbspro.2010.12.348

[2] Kağizmanli, T. B., Tatar, E., \& Akkaya, A. (2011). Analytic analysis of lines with dynamic mathematical software. Procedia - Social and Behavioural Sciences, 15, 2505-2509. https://doi.org/10.1016/j.sbspro.2011.04.136

[3] Wijaya, T.T., Ying, Z., \& Suan, L. (2020a). Gender and Self-regulated Learning During COVID-19 Pandemic in Indonesia. Jurnal Basicedu, 4(3), 725-732. https://doi.org/10.31 004/basicedu.v4i3.422

[4] Wijaya, T.T., Ying, Z., \& Purnama, A. (2020). Using Hawgent Dynamic Mathematics Software in Teaching Trigonometry. International Journal of Emerging Technologies in Learning, 15(10), 215-222. https://doi.org/10.3991/ijet.v15i10.13099

[5] Astuti, D., Anggraeni, L., \& Setyawan, F. (2020). Mathematical probability: Student's misconception in higher education. Journal of Physics: Conference Series, 1613(1). https://doi.org/10.1088/1742-6596/1613/1/012009 
[6] Fitriani, N., Suryadi, D., \& Darhim, D. (2018). the Students' Mathematical Abstraction Ability Through Realistic Mathematics Education With Vba-Microsoft Excel. Infinity Journal, 7(2), 123. https://doi.org/10.22460/infinity.v7i2.p123-132

[7] Wijaya, T T, Ying, Z., Chotimah, S., Bernard, M., Zulfah, \& Astuti. (2020c). Hawgent dynamic mathematic software as mathematics learning media for teaching quadratic functions. Journal of Physics: Conference Series, 1592(1). https://doi.org/10.1088/1742-6596/ $\underline{1592 / 1 / 012079}$

[8] Surya, Y. F., Zulfah, Astuti, Marta, R., \& Wijaya, T. T. (2020). The Development of Open-Ended Math Questions on Grade v Students of Elementary School. Journal of Physics: Conference Series, 1613(1). https://doi.org/10.1088/1742-6596/1613/1/012081

[9] Wijaya, T.T., Ying, Z., \& Suan, L. (2020b). Using Geogebra in Teaching Plane Vector. Journal of Innovative Mathematics Learning, 3(1), 15-23.

[10] Wijaya, T. T., Jianlan, T., \& Purnama, A. (2020). Developing an Interactive Mathematical Learning Media Based on the TPACK Framework Using the Hawgent Dynamic Mathematics Software. Emerging Technologies in Computing, 318-328. https://doi.org/10.1007 1978-3-030-60036-5

[11] Al-Mashaqbeh, I. F. (2016). IPad in elementary school math learning setting. International Journal of Emerging Technologies in Learning, 11(2), 48-52. https://doi.org/10.3991/ijet. $\underline{\mathrm{v} 11 \mathrm{i} 02.5053}$

[12] Baya'a, N., \& Daher, W. (2013). Mathematics teachers' readiness to integrate ICT in the classroom. International Journal of Emerging Technologies in Learning, 8(1), 46-52. https://doi.org/10.3991/ijet.v8i1.2386

[13] Mushipe, M., \& Ogbonnaya, U. I. (2019). Geogebra and Grade 9 learners' achievement in linear functions. International Journal of Emerging Technologies in Learning, 14(8), 206219. https://doi.org/10.3991/ijet.v14i08.9581

[14] Yadav, S., Chakraborty, P., Kochar, G., \& Ansari, D. (2020). Interaction of children with an augmented reality smartphone app. International Journal of Information Technology, 12(3), 711-716. https://doi.org/10.1007/s41870-020-00460-6

[15] Gobec, K., \& Strgar, J. (2019). Effectiveness of the Conceptual Change Method on Understanding Plant Mass Increase. Journal of Baltic Science Education, 18(4), 569-582. https:// doi.org/10.33225/jbse/19.18.569

[16] Alaboudi, A., \& Alharbi, A. S. (2020). Impact of digital technology on Saudi students. International Journal of Information Technology. https://doi.org/10.1007/s41870-020-00451$\underline{7}$

[17] Zhang, L., Zhou, Y., \& Wijaya, T. T. (2020). Hawgent dynamic mathematics software to improve problem-solving ability in teaching triangles. Journal of Physics: Conference Series, 1663(1). https://doi.org/10.1088/1742-6596/1663/1/012069

[18] Wijaya, T.T., Ying, Z., \& Purnama, A. (2020a). The empirical research of hawgent dynamic mathematics technology integrated into teaching. Journal Cendekia: Jurnal Pendidikan Matematika, 04(01), 144-150.

[19] Chotimah, S., Wijaya, T. T., Aprianti, E., Akbar, P., \& Bernard, M. (2020). Increasing primary school students' reasoning ability on the topic of plane geometry by using hawgent dynamic mathematics software. Journal of Physics: Conference Series, 1657(1), 012009. https://doi.org/10.1088/1742-6596/1657/1/012009

[20] Lin, Y. L., Huang, S. W., \& Chang, C. C. (2019). The impacts of a marine science board game on motivation, interest, and achievement in marine science learning. Journal of Baltic Science Education, 18(6), 907-923. https://doi.org/10.33225/jbse/19.18.907 
[21] Suan, L., Ying, Z., \& Wijaya, T. T. (2020). Using hawgent dynamic mathematics software in teaching arithmetic operation. International Journal of Education and Learning, 2(1), 25-31. https://doi.org/10.31763/ijele.v2i1.97

[22] Tan, S., Zou, L., Wijaya, T. T., Suci, N., \& Dewi, S. (2020). Improving student creative thinking ability with problem-based learning approach using hawgent. Journal on Education, 02(04), 303-312.

[23] Tan, S., Wijaya, T. T., Zou, L., \& Hermita, N. (2020). Proving the Formula for the Area of a Circle using Hawgent Dynamic Mathematics Software. Journal of Physics: Conference Series, 1655(1), 012052. https://doi.org/10.1088/1742-6596/1655/1/012052

[24] Kaur, B., Zhu, Y., \& Cheang, W. K. (2019). Singapore's Participation in International Benchmark Studies-TIMSS, PISA and TEDS-M. Mathematics Education - An Asian Perspective, 101-137. https://doi.org/10.1007/978-981-13-3573-0_6

[25] Leksmono, A., Sunardi, Prihandoko, A. C., \& Murtikusuma, R. P. (2019). Students' creative thinking process in completing mathematical PISA test concerning space and shape. Journal of Physics: Conference Series, 1211(1). https://doi.org/10.1088/1742-6596/1211/ $1 / 012073$

[26] Retnawati, H., \& Wulandari, N. F. (2019). The development of students' mathematical literacy proficiency. Problems of Education in the 21st Century, 77(4), 502-514. https://doi. org/10.33225/pec/19.77.502

[27] Rohaeti, E. E., Bernard, M., \& Primandhika, R. B. (2019). Developing interactive learning media for school level mathematics through open-ended approach aided by visual basic application for excel. Journal on Mathematics Education, 10(1), 59-68. https://doi.org/10. 22342/jme.10.1.5391.59-68

[28] Wonganu, P., Chaijaroen, S., \& Vongtathum, P. (2019). Designing Framework of Constructivist Digital Learning Environment Model to Enhance Creative Thinking for Undergraduate Students. In Lecture Notes in Computer Science (including subseries Lecture Notes in Artificial Intelligence and Lecture Notes in Bioinformatics). https://doi.org/10.1 $\underline{007 / 978-3-030-35343-8 \_26}$

[29] Runisah. (2019). The effect of 5E learning cycle with metacognitive techniques and mathematical prior ability on mathematical creative thinking skills. Journal of Physics: Conference Series, 1315(1). https://doi.org/10.1088/1742-6596/1315/1/012082

[30] Rohaeti, E. E., Bernard, M., \& Novtiar, C. (2019). Pengembangan Media Visual Basic Application untuk Meningkatkan Kemampuan Penalaran Siswa SMP dengan Pendekatan Open-Ended. Supremum Journal of Mathematics Education, 3(2), 95-108.

[31] Huang, M. C. L., Chou, C. Y., Wu, Y. T., Shih, J. L., Yeh, C. Y. C., Lao, A. C. C., ... Chan, T. W. (2020). Interest-driven video creation for learning mathematics. In Journal of Computers in Education (Vol. 7). https://doi.org/10.1007/s40692-020-00161-w

[32] de Losada, M. F. (2017). Are Mathematics Competitions Changing the Mathematics that Is Being Done and the Way Mathematics Is Done? 329-350. https://doi.org/10.1007/978-3319-56585-9 13

[33] Mohamadi, Z. (2018). Comparative effect of project-based learning and electronic projectbased learning on the development and sustained development of English idiom knowledge. Journal of Computing in Higher Education, 30(2), 363-385. https://doi.org/ 10.1007/s12528-018-9169-1

[34] Bernard, M., Akbar, P., Ansori, A., \& Filiestianto, G. (2019). Improve the ability of understanding mathematics and confidence of elementary school students with a contextual approach using VBA learning media for Microsoft Excel. Journal of Physics: Conference Series, 1318(1). https://doi.org/10.1088/1742-6596/1318/1/012035 
[35] Chotimah, Siti, Bernard, M., \& Wulandari, S. M. (2018). Contextual approach using VBA learning media to improve students' mathematical displacement and disposition ability. Journal of Physics: Conference Series, 948(1). https://doi.org/10.1088/1742-6596/948/1/ $\underline{012025}$

[36] Fitri, S., Syahputra, E., \& Syahputra, H. (2019). Blended learning rotation model of cognitive conflict strategy to improve mathematical resilience in high school students. International Journal of Scientific and Technology Research, 8(12), 80-87.

[37] Hendriana, H., Eti Rohaeti, E., \& Hidayat, W. (2017). Metaphorical thinking learning and junior high school teachers' mathematical questioning ability. Journal on Mathematics Education, 8(1), 55-64. https://doi.org/10.22342/jme.8.1.3614.55-64

[38] Wiranota, H., \& Wijaya, T. T. (2021). The international students' perception towards online learning using the tencent meeting during covid-19 outbreak the international students' perception towards online learning using the tencent meeting during covid-19 outbreak. Journal of Physics: Conference Series, 1823. https://doi.org/10.1088/1742-6596/18 23/1/012011

[39] Agyei, D. D. (2019). From needs analysis to large-scale implementation: Using collaborative design to support ICT integration. Collaborative Curriculum Design for Sustainable Innovation and Teacher Learning, 305-328. https://doi.org/10.1007/978-3-030-20062-6 $\frac{17}{R}$

[40] Roth, M. A., \& Price, J. K. (2016). ICT in Education in Global Context. In Lecture Notes in Educational Technology. https://doi.org/10.1007/978-3-662-47956-8

[41] Khairunnisa. (2018). Task design for improving students' engagement in mathematics learning. Journal of Physics: Conference Series, 948(1). https://doi.org/10.1088/1742$\underline{6596 / 948 / 1 / 012012}$

[42] Mohamadi, Z. (2018). Comparative effect of project-based learning and electronic projectbased learning on the development and sustained development of english idiom knowledge. Journal of Computing in Higher Education, 30(2), 363-385. https://doi.org/10.1007/s12528-018-9169-1

[43] Caroline R., P., \& Rui, K. (2013). Project-Based Learning. STEM Project-Based Learning, (1998), 129-138.

[44] Gil, P., \& Gil, P. (2017). Short Project-Based Learning with MATLAB Applications to Support the Learning of Video-Image Processing. 508-518. https://doi.org/10.1007/s109 $\underline{56-017-9695-\mathrm{Z}}$

[45] Ketelhut, D. J. (2019). Contemporary Technologies in Education. Contemporary Technologies in Education, 17-29. https://doi.org/10.1007/978-3-319-89680-9

[46] Chang, Y. J., Wang, T. Y., Chen, S. F., \& Liao, R. H. (2011). Student Engineers as Agents of Change: Combining Social Inclusion in the Professional Development of Electrical and Computer Engineering Students. Systemic Practice and Action Research, 24(3), 237-245. https://doi.org/10.1007/s11213-010-9183-3

[47] Cunhua, L., Ying, Z., Qunzhuang, O., \& Wijaya, T. T. (2019). Mathematics course design based on six questions cognitive theory using hawgent dynamic mathematic. Journal On Education, 02(01), 36-44.

[48] Wijaya, T. T. (2021). How Chinese students learn mathematics during the coronavirus pandemic. International Journal of Educational Research and Innovation (IJERI), 15, 1-16. https://doi.org/https://doi.org/10.46661/ijeri.4950

[49] Zhang, X., Zhou, Y., \& Wijaya, T. T. (2020). Hawgent Dynamic Mathematics Software to Teach Line and Angle. JNPM (Jurnal Nasional Pendidikan Matematika), 4(2), 237-247.

[50] Koh, J. H. L., Chai, C. S., \& Tsai, C. C. (2013). Examining practicing teachers' perceptions of technological pedagogical content knowledge (TPACK) pathways: A structural 
Paper-Improving the Creative Thinking Skills of the Next Generation of Mathematics Teachers Using...

equation modeling approach. Instructional Science, 41(4), 793-809. https://doi.org/10.1 007/s11251-012-9249-y

[51] Aflatoony, L., \& Wakkary, R. L. (2015). Thoughtful thinkers: Secondry Schoolers' learning about design thinking. Learn design, 563-574.

\section{$7 \quad$ Authors}

Tommy Tanu Wijaya completed his undergraduate study in mathematics Education at IKIP Siliwangi, Indonesia. Has a master's degree in mathematics and statistics from Guangxi Normal University, Guilin, China. Address: Guangxi Normal University, Yanshan no. 1, Guilin, China. Interest in research areas, including (1) mathematics teaching and learning, (2) improve students' mathematical skill, (3) ICT, (4) Dynamic Mathematics software, (5) High Order Thinking Skill, and (6) Mathematics for Elementary School. Email: tanuwijayat@stu.gxnu.edu.cn

Ying Zhou is a Professor of Mathematics Education at Guangxi Normal University, China. email: zhouying66@mailbox.gxnu.edu.cn

Neni Hermita is a Lecturer at Universitas Riau, Indonesia. Email: neni.hermita@ lecturer.unri.ac.id

Andrew Ware is a Professor of Computing at the University of South Wales in the United Kingdom. His research interest centre on the use of computer-based applications to help solve real-world problems. Email: andrew.ware@southwales.ac.uk

Article submitted 2021-01-27. Resubmitted 2021-04-20. Final acceptance 2021-04-20. Final version published as submitted by the authors. 